Human Rights, International Courts and Deliberative Democracy

Roberto Gargarella

The aim of this paper is to discuss about some legal problems generated by situations of gross violations of Human Rights, and to do so from the perspective of a "communicative" approach to the Criminal Law. I am interested in stressing the importance of having an inclusive collective discussion for deciding how to deal with situations of massive violation or rights -and particularly of showing the legal implications of not having such a collective debate. In this exploration, I will frequently back my arguments with the theoretical views of two authors, namely Antony Duff and Carlos Nino.

In the first part of my paper, I contrast Antony Duff's communicative view -as applied to the analysis of International Criminal Law- with alternative approaches. Then, I examine the connection of this communicative perspective with a deliberative conception of democracy. In the second part of my paper, I try to demonstrate the merits of this approach for dealing with hard cases involving gross violations of Human Rights and the participation of foreign tribunals. In this final part, I test the potential of the deliberative view in three real and recent hard cases. The examples that I take into account are the case of the 1983 selfamnesty Law in Argentina (a self-amnesty passed by members of the last Military Junta, before handing over power to the new democratic authorities); and the Barrios Altos and Simón cases, which also involved amnesties directed at pardoning gross violations of human rights (amnesties that, in these cases, were not passed by military regimes, but rather by democratic or -in the case of Barrios Altos- quasi-democratic/quasi-authoritarian governments).

International Criminal Law According to Antony Duff

In a recent paper on International Criminal Law, Antony Duff challenges two very important approaches to just law, from a "communicative” legal perspective (Duff 2008). The first view, legal positivism, sees judges as simply "strict enforcers" of the law that is created by political authorities: what matters, in this case, is that the law has been enacted by an authority that has the power to do so. The second view, in contrast, derives justice from the existence of a just procedure. 
i) Justice and legal positivism. On the one hand, Duff's conception defies traditional legal positivist analyses, according to which the authority of the law derives from the fact that it is imposed from above by an authorized sovereign. The positivist approach recognizes different presentations, one of the most common and disputable being the one that simply asserts that "the law is the law" (Gesetz ist Gesetz): the law has to be obeyed because it is the law. Norberto Bobbio named this view "ideological positivism," namely the sort of positivism which maintains that $\mathrm{i}$ ) that the law is just because it derives from a legal authority (which is to say that the law is valid because it is in force); and ii) that the law must be respected because it contributes to the achievement of important social goals, such as social order, peace, certainty, regardless of the intrinsic value of its specific rules (Bobbio 1965, 47). ${ }^{1}$ Alf Ross named this same view "pseudo-positivism," which he associated with Martin Luther and Hegel's philosophy. According to this version of positivism, the dominant order must be obeyed simply as a consequence of the fact that it is the dominant order (Nino 1980). ${ }^{2}$ Defying this understanding of the law is an important first step because numerous legal practitioners seem to implicitly adopt such a view when they analyze the functioning of the international law and international courts -they imply, for example, that decisions from international tribunals must be respected because they represent the law in force.

Now, Duff is particularly concerned with resisting “Austinian” versions of positivism. As we know, legal positivists like Austin wanted to sever law from morality. By stating this, legal positivists were reacting to alternative, normative rather than descriptive approaches, which considered the law as valid in so far as it reflected the community's values, or customs, or fulfilled certain -more objective- criteria of justice. "Austinians" wanted to offer a descriptive, conceptual approach to the law, which did not take into account questions about what the law should be or become. In sum, this positivist "top-down” theory of law described laws as commands backed by sanctions and issued by an uncontrolled commander, namely the sovereign.

Consistently with this criticism, in his recent study of international law, Duff challenged the "Austinian answer" according to which "defendants are called to account by the sovereign whose orders they have allegedly disobeyed, in virtue of the sovereign's authority (or power) over them.” This view, however, does not fit well with the idea of a selfgoverning community, which cares who decides what and for what reasons. Then, and

\footnotetext{
${ }^{1}$ Bobbio, N. (1965), El problema del positivismo jurídico, EUDEBA, Buenos Aires.

${ }^{2}$ Nino, C. (1980), Introducción al análisis del derecho, Astrea, Buenos Aires.
} 
against this view, he proposes a different answer, which maintains that "defendants are answerable to their fellow citizens (in whose name the courts act) for public wrongs that they commit, in virtue of their shared membership of the political community.”

ii) Justice and Due Process. On the other hand, Duff's approach challenges the idea that any State could judge violations committed in other States, as long as a champagne-quality due process is put in place (Luban 2004). He claims that the fairness of the process is essential, but that it is also essential for it to be conducted by those who have the authority to do it. He summarizes his view through this example:

Suppose that a group of my neighbors, worried about the decline in marital fidelity, take it upon themselves to bring local adulterers to book, and turn their attention to me, as an alleged adulterer. I might not deny that adultery is wrong, or that I am an adulterer who must answer for his adultery to those whose business it is-to my wife and family, to our mutual friends. But I might reasonably insist that it is not my neighbors' business: they have no right to call me to answer for my adultery; nor can the fairness of their procedure give them that right. Now a criminal trial, I will argue, should be understood as a process which calls alleged wrongdoers to answer charges of wrongdoing, and to answer for such wrongdoing if it is proved against them. The legitimacy of that process depends both on its procedural fairness, and on the court's authority to call the defendant to answer; a deficiency in one of these dimensions cannot be compensated by adequacy, or even by perfection, in the other.

In his view, the wife of the adulterer (or maybe his Church) can have the relevant standing for reproaching him for his conduct -they represent the "relevant public," the relevant "we", in the end the relevant "community"-, but not his neighbors, even if they managed to organize a fair process. Only the relevant community -he adds- can call me to account for what I did. However, it is worth noting that he maintains a rather weak notion of community as he says "Once we recognize that a community, in the sense relevant here, need not involve close ties or deep structures of richly shared interests, we will see that we can talk of the human community without espousing any radical, and controversial, form of cosmopolitanism”. This and other reasons make him open to the (limited) intervention of foreign tribunals, although he also maintains the clear priority of local tribunals. ${ }^{3}$ Regarding foreign magistrates he claims that "a regime is unlikely to put its own officials on trial; even when it falls, its successor might be reluctant to prosecute such crimes. In such cases, if the crimes are serious enough to warrant the costs involved, it might be appropriate for an

\footnotetext{
${ }^{3}$ He maintains, for instance, that "Augusto Pinochet was answerable to the Chilean people for the crimes he committed against them (individually and collectively), and should properly have been called to account in a Chilean court.”
} 
international court to claim jurisdiction or, absent such a court, for courts of other states to claim jurisdiction on behalf of the citizens whose own courts have let them down.”

Duff's criticisms to existing approaches to Criminal Law come from a specific normative view, which we may call a communicative approach. For Duff, "to put someone on trial, and to punish him for his wrongdoing, is to treat him as a member of the normative community under whose laws he is tried and punished.” The accused has to be addressed as a "fellow member of a normative community whose values he can be expected to understand and accept” (Duff 2008). ${ }^{4}$ What this approach aims to do is enter into a moral dialogue with the offender, in order to communicate to him the social condemnation of what he has done. ${ }^{5}$ What we need is to strengthen his or her links to the rest of us, and convince him or her that there are important reasons for him or her to obey the law (which presupposes that he or she has reasons to recognize his or herself as an author of the law). Here, I will be concerned with one aspect of this communicative theory, which has to do with the importance of entering into a moral dialogue for deciding about basic questions of human rights. Those fundamental public questions need to be fully and collectively discussed, rather than simply be decided by an authority endowed with coercive powers. The absence of such public debate must have legal consequences that should not be ignored -as they usually are.

The Communicative Approach and Deliberative Democracy

Duff's communicative approach to the Criminal Law seems to be dependent on a broader normative theory of democracy, namely a deliberative theory of democracy. Of course, there are many different versions about what a deliberative democracy is, and we do not need to go into a detailed discussion about its meaning, scope and limits. For the purposes of this paper, both the work of Habermas (1996) and Nino (1996) represent good examples of interesting and contemporary approaches to the idea of deliberative democracy. For Jurgen Habermas, the legitimate law requires a process of public discussion that included "all those potentially

\footnotetext{
${ }^{4}$ Duff describes the Criminal process as a communicative process, which should not be simply confused with "expressive" approaches to Criminal Law, like those advanced by Joel Feinberg or Jean Hampton (Feinberg 1970, Hampton 1984). ${ }^{4}$ According to Feinberg, "punishment is a conventional device for the expression of attitudes of resentment and indignation, and of judgments of disapproval and reprobation, on the part either of the punishing authority himself or of those 'in whose name' the punishment is inflicted" (Feinberg 1970, 96). The communicative approach, instead, sees the Criminal process as a "two-way"- process, where one part tries to actively address the other, resorting to his reason, rather than his fear (see below).

${ }^{5}$ This approach should not be classified as consequentialist because, as Duff and Garland maintain, it proposes engaging in this communicative effort even though we were sure that the offender would remain unmoved and unreformed by our expressions (Duff and Garland 1994, 15).
} 
affected” (Habermas 1996). Similarly, Carlos Nino proposed an epistemic approach to deliberative democracy, which connected the impartiality of norms with an inclusive process of collective discussion (Nino 1996. See also Habermas 1996; Nino 1993; Pettit 1997b). Moreover, both views appear to be committed to a (substantial, material) notion of equality, which they consider a crucial condition for ensuring civic participation and deliberation.

In sum, for those who assume this deliberative view, legal norms should be the product of i) a broad collective public discussion; in which all those potentially affected by those legal norms take part. Inclusiveness and public discussion appear, then, as the two main requirements for a law to be considered a legitimate law.

Of course, these are the demanding conditions of a highly demanding regulative ideal. But it is important not to exaggerate the idealistic nature of this view. Finally, what this theory does is to take seriously and refine some common-sense considerations about the law, and the conditions that contribute in making the law more impartial -meaning less biased in favor of particular groups. Deliberative democrats contrast deliberative processes based on arguments with other processes merely based on bargaining (Sunstein 1985; Elster 1991). ${ }^{6}$ Consequently, they suggest different ways of strengthening the impartiality of laws and reducing the risks of improper biases. In this respect, they refer to the dangers posed to impartiality by say, an improper distribution of information; the lack of proper, open discussion; the systematic absence of certain viewpoints; economic and social inequality; etc. These reasonable concerns explain their interest in social inclusion, public discussion, the distribution of information, or basic equality.

Until recently, Duff did not openly refer to the connection between his own communicative- view on Criminal Law and this theory of democracy, probably because he did not find it necessary to cross the borders of the Criminal Law in order to write what he wanted to write. ${ }^{7}$ However, in his more recent work he has made this connection more explicit (Duff and Marshall 2007; Duff, Farmer et al. 2007). He thus looked for support in "participatory and deliberative conceptions of democracy" for supporting his view of the trial

\footnotetext{
${ }^{6}$ It is in this respect that I would defend, with Carlos Nino, the epistemic virtues of a system of deliberative democracy (see Nino 1996).

${ }^{7}$ Similarly, and given the rather "natural" or obvious connections between a deliberative view of democracy and a communicative understanding of punishment, it is surprising that authors such as Carlos Nino did not make or pursue that connection. Nino began and ended his academic career writing about Criminal Justice (Nino 1980, 1996b) and in between both extremes, dedicated almost two decades to developing a powerful approach to deliberative democracy (Nino 1996). Pablo de Greiff rightly point out this missing connection, making reference to the fact that, in his latest writings, Nino still founded his views on Criminal Justice from moral premises alone, leaving no clear role to his views on democratic legitimacy (de Greiff 2002, 383).
} 
as a "process of calling to account, as just one of the various ways in which, as participants in the wide range of practices of reason that structure our lives, we hold each other responsible" (Duff and Marshall 2007, 220, 241). ${ }^{8}$ So, I now want to pause for a while and explore some of the implications deriving from that broader view.

Deliberative Democracy and the Creation of the Criminal Law

It seems clear that deliberative theory may improve our understanding and critical analysis of the Criminal procedure, as Antony Duff has shown us, through his communicative view. However, deliberative theory is potent enough to help us go beyond the limits of the Criminal Process and examine the very content of Criminal Law. This is to say, the principles of social inclusion and collective deliberation that we explored in the previous section could and should be used to look at our subject - Criminal Law- as a whole.

This concern with the content of the law and its validity is always important, but particularly so when we are dealing with the use of the State's coercive apparatus in its most brutal forms. And this concern is even more important when what is at stake is the justification of the use of that force in the context of highly unequal societies. Ultimately -I submit- the law does not deserve respect if individuals do not have good reasons to believe that it properly reflects their views and interests -if the law appears to be, as usually happens in many contemporary societies- partial or non-neutral, meaning the mere product of the will of the dominant group. ${ }^{9}$ The intuition behind this point is that the systematic absence of certain viewpoints from the decision-making process seriously threatens the impartial character of that process, and thus of Law itself. That systematic absence seriously increases the presumption that Criminal laws are going to be written, applied and interpreted by only a part of society, for its own benefit. We then face the possibility that a group uses the State's coercive means for enforcing an unjust social order.

\footnotetext{
${ }^{8}$ Duff, A., and Marshall, S. (2007) “Criminal Responsibility and Public Reason,” in M. Freeman and R. Harrison, Law and Philosophy, Oxford: Oxford U.P.

Duff, A.; Farmer, L.; Marshal, S.; Tadros, V. (2007), The Trial on Trial: Towards a Normative Theory of the Criminal Trial, Hart Publishers.

${ }^{9}$ For Duff "Part of the value of this conception of criminal trials is that it emphasizes the defendant's status, not as an enemy or a dangerous threat who must be destroyed or rendered impotent, but as a fellow member of a normative community who is called to answer to his fellows for what he has done-and whose fellows must be ready to answer to him for their treatment of him.”
} 
In his most recent work, Duff has also taken this step, and focused his attention on the very content of Criminal Law. Using a deliberative perspective he puts the content of Criminal Law under critical analysis. For him, the legitimacy of the law must "be grounded not merely in its majoritarian credentials, but in the process of public deliberation and debate from which it emerged -a process that can be itself be legitimate (and thus can ground the law's legitimacy- only if structured by a due respect for the standing of all the citizens who are to be participants in it. Such a respect, for citizens as responsible agents who can take part in such an enterprise of self-government, will constrain the possible content of the criminal law in ways that simple majoritarianism cannot, since a collective and mutually respectful deliberation must generate laws that themselves express the respect and protect the rights that it recognizes” (Duff and Marshall 2007. 238. See also Nino 2008).

The Impact of the Deliberative Approach in the Analysis of Human Rights Cases: The SelfAmnesty Law in Argentina

Once we have introduced the deliberative approach, one crucial query is whether and in what way this view may help us in the analysis of actual legal conflicts. The answer to this question may seem problematic for different reasons, as it is one of the most important the difficulties that we obviously face when we want to take the requirements of inclusiveness and public deliberation seriously. The questions that then appear are many: How much deliberation is enough? How inclusive should the decision-making process be, in order to be unquestionable? What does inclusiveness mean, in the context of a representative democracy? How to evaluate a situation where we seem to do well in terms of deliberation and bad in terms of inclusiveness? The fact is that we radically and reasonably disagree regarding how to answer questions of the like. They are obviously difficult -although, I would add, not impossible- to answer, but in any case the complexities that we face should not paralyze us. In the end, we should never forget that we are dealing with the most extreme cases involving the use of the State's coercive powers, and that we are usually being too flexible, rather than too demanding, regarding the standards we use to evaluate those actions.

Now, no matter the difficulties we have, on deciding when a norm is irreproachably impartial, it would still be possible to define certain thresholds below which a norm should be considered (morally and legally) unacceptable. For example, it should be clear that all norms enacted by a dictatorial government are not above the threshold, particularly as a consequence of their extreme violation of the requisite of inclusiveness. In this respect, one 
may reasonably say, norms that emerge from an authoritarian, non-democratic government should always be presumed to be invalid, even in the case that, as a result of other reasons (for example, to avoid legal chaos) we finally decided not to invalidate all the marriages agreed or contracts signed during those years, under invalid norms (Nino, La validez del derecho)

This point has enormous consequences for the analysis of recent violations of Human Rights. For instance, important members of the legal communities in Chile and Argentina disagreed regarding when to talk about a valid law, in the face of statutes that were passed by military governments. In one of the few instances where the Chilean Supreme Court tried to answer to the serious criticisms that it was receiving for its lack of commitment to the protection of human rights, the Court stated:

It has been said that the judiciary is weak, and that such weakness manifests itself in the incapacity to search for the ethical ideals of the law and the Chilean society...Courts are strict and loyal law enforcers, law that continues to be for them the written reason. According to such law, the judges ought to decide cases... and they are not authorized to disdain and deviate from this rule and look for general principles of morality or law which could produce their decisions... The judges are aware that they must be strict appliers of the law. ${ }^{10}$

This response is representative of the most extreme version of legal positivism explored in the first section of this paper, this is to say, ideological positivism. According to the view advocated by Chilean Justices, the law is considered valid law because of the very fact that it is the law in force. In that context, their own mission seems to be that of being "strict enforcers of the law." A few years after this declaration, the Chilean National Commission for Truth and Reconciliation wrote a critical report on the behavior of the Judiciary during General Pinochet's years. The Commission criticized the "lack of effort of many judges to fully comply with their obligation of securing due respect for the essential rights of the people," and the Court quickly replied to these accusations by saying that judges were "and ought to be the strict appliers of the law. For the laws continued to be written reason, born as a product of the contingencies of a given time and place. The judges have to decide cases according to the law." 11 Again, Chilean Justices described themselves as mere "enforcers of the law."

Meanwhile, in Argentina, a different approach to the validity of the law, promoted by a number of legal scholars, allowed the newly elected democratic government to invalidate

\footnotetext{
${ }^{10}$ I take this statement from Correa Sutil (), 91. Correa Sutil, J. “The Judiciary and the Political System in Chile: The Dilemmas of Judicial Independence During the Transition to Democracy,” in Irwin Stotzky, ed., Transition to Democracy in Latin America: The Role of the Judiciary, Westview Press.

${ }^{11}$ Ibid., 99.
} 
the self-amnesty law that was passed by the military government before transferring political power to the new democratic authorities. Notably, this renewed approach to the validity of the law was explicitly based on a theory of deliberative democracy, like the one that we presented in previous sections. The self-amnesty law was considered invalid, among other reasons, because of the exclusionary characteristics of the process through which it had been created.

Law 22.934 or the self-amnesty law was imposed by the Argentinean military government before handing over its power to civilian authorities. The amnesty was enacted under General Bignone’s government, on September 23, 1983, and was presented as an attempt to ensure the "pacification of the country" and "social reconciliation." The norm came to pardon all "subversive and anti-subversive" acts, including common and military crimes, committed between May 1973 and June 1982, and covered all those who had collaborated in those illegal activities. It excluded, however, those members of terrorist organizations who were not at the time residing in Argentina, or continued developing subversive activities. Among other things, the norm also prohibited judicial interrogating those involved in the pardoned acts.

For incoming civilian authorities, the self-amnesty law represented a serious legal obstacle. The law made it very difficult for democratic authorities to deal with past massive crimes and gross violations of human rights. The Peronist Party, which at the time appeared to be the strongest national party, had committed itself to pay due respect to the self-amnesty law. The then president of the Peronist Party, Italo Luder, a noted constitutional lawyer, maintained that the law could not be invalidated, given that i) the National Penal Code granted offenders the application of the most favorable law existing from the time of the crime to the sentencing, and ii) the Constitution proscribed retroactive penal legislation (Nino 1996, 65). The second largest Party (which then, surprisingly, won the national election), the Radical Party, had instead promised to challenge the validity of that law. The problem, however, was how to justify and ensure that goal, in case of becoming elected.

Remarkably, the two most important intellectuals involved in this process of legal revision were two well-known legal philosophers, namely Genaro Carrió ${ }^{12}$ and Carlos Nino. Carrió proposed the derogation of the self-amnesty law, arguing that it violated Argentina's former Constitution, which maintained that "Congress may not vest on the National

\footnotetext{
${ }^{12}$ A famous lawyer and future Chief Justice of the Supreme Court, Carrió was also one of the introducers of analytical philosophy in Argentina.
} 
Executive Power -nor may the provincial legislatures vest on the provincial governorsextraordinary powers or the total public authority," and neither "grant acts of submission or supremacy whereby the life, honor or wealth of the Argentine people will be at the mercy of governments or any person whatsoever" (article 29). The other noted jurist involved in the process was Carlos Nino -who was an early proponent of a deliberative conception of democracy. Nino's argument, at that time, was consistent with his general theoretical understanding of the law. He proposed challenging the entire de facto legislation, as a consequence of his particular (epistemic) conception of democracy. For him, and given the "epistemic character of the democratic process," "only norms with democratic origin enjoy a presumption of moral acceptability” (Nino 1996, 66). These norms could be deemed valid, in principle, as a result of their being the product of a collective dialogue that involved all those potentially affected (Nino 1996). ${ }^{13}$

By saying that laws enacted by the dictatorship could not be presumed to be valid, Nino challenged dominant legal and judicial doctrine in Argentina. For him, the self-amnesty law passed by the military government, lacked any presumption of validity (among other things), because of the exclusionary characteristics of the process through which it had been created. In our terms, he claimed that laws created through a totally exclusionary decisionmaking process could not be deemed prima facie valid.

Ultimately, and referring to criteria such as those advanced by Carlos Nino, Argentine National Congress finally nullified the self-amnesty law. Congress did so through the historic nullification law 23.040, which allowed the launching of the also historic trials against the main members of the Military Junta.

Deliberative Democracy in Hard Cases: Barrios Altos and Simón

\footnotetext{
${ }^{13}$ Nino had publicly advanced that view in a letter to one of Argentina's main newspaper, which he wrote in the company of some of the most distinguished legal philosophers of the country, including the same Carrió, Jaime Malamud Gotti, Eduardo Rabossi and Jorge Bacqué. In their letter, the philosophers claimed that validity was “an evaluative concept...integrally linked to morality," and advanced Nino's criticisms to de facto norms. For Nino, traditional defenses of these norms were based on a "naturalistic fallacy, so characteristic of positivism." In his view, "in determining the normative binding force of legal norms, empirical facts such as normative efficacy and the distribution of power to enact such norms inform evaluations" (Nino 1996, 66) . He thus rejected what amounted to be a represented mere exercise of dogmatic (ideological) positivism, which is to say, an absurd attempt to validate the law because it is the law "in force" -a way of saying that "the law is (valid because it is) the law."
} 
The deliberative approach seems to be extraordinarily potent for making a case against the validity of the laws passed by a military dictatorship - a case that is not easy to make, even though it would be defended by many authors, coming from different argumentative traditions. In this section, I want to test the strength of the deliberative approach in more difficult cases, also related to massive violations of human rights, but involving legislation that was not originated in a military regime. In order to explore the force of the theory in this difficult territory, I will take two important and recent examples, namely the Barrios Altos case, decided by the Inter American Court of Human Rights, and the Simón case, decided by Argentina's Supreme Court. In both cases we have pardon-laws, which came to prevent the prosecution of massive human rights violations. The former pardon was issued by Fujimori's authoritarian regime -the President had shut down Congress and public debate was severely restricted-, while the latter was passed by a new and legitimate democratic regime, presided by Raúl Alfonsín.

The Barrios Altos case. This case refers to a massacre that took place in Peru on 3 November 1991, in the poor neighborhood of Barrios Altos, during Alberto Fujimori’s presidency. The massacre (15 totally innocent people were killed) was committed by a death squad affiliated to the government, which was looking for members of the terrorist group Sendero Luminoso. Some years later, judicial investigations began, but Congress prevented the development of those trials by passing Law No. 26479, which granted a general amnesty to all those subject to a complaint, investigation, indictment, trial or conviction, or who were serving prison sentences, for human rights violations committed after May 1980. It must be noted that this amnesty law was passed by a government that had undermined democratic institutions -it had shut down Congress- and severely affected the openness of the democratic debate. In any case, after the fall of Fujimori, the amnesty law was derogated, and the case re-opened. In a decision on March 14, 2001, the Inter-American Court of Human Rights maintained that amnesty laws aimed at preventing the investigation of grave violation of human rights contradicted the International Law of Human Rights.

In order to maintain that Fujimori contradicted international law, the Inter American Court of Human Rights made reference to strictly legalistic reasons. In a central part of its reasoning, the ICHR stated

42. The Court, in accordance with the arguments put forward by the Commission and not contested by the State, considers that the amnesty laws adopted by Peru prevented the victims' next of kin and the surviving victims in this case from being heard by a judge, as established in Article 8(1) of the Convention; they violated the right to judicial protection embodied in Article 25 of the Convention; they prevented the investigation, 
capture, prosecution and conviction of those responsible for the events that occurred in Barrios Altos, thus failing to comply with Article 1(1) of the Convention, and they obstructed clarification of the facts of this case. Finally, the adoption of self-amnesty laws that are incompatible with the Convention meant that Peru failed to comply with the obligation to adapt internal legislation that is embodied in Article 2 of the Convention. ${ }^{14}$

The reasons mentioned by the Court in support of its ruling were important and necessary but, at the same time, it is worth noting that the tribunal did not dedicate any special attention to the crucial fact that the amnesty law was decided by those who would benefit from it, and created through a highly questionable decision-making process, which put the validity of those norms in question.

The Simón case. Before leaving power, Argentina’s last dictatorship (1976-1983) approved a self-amnesty law, which came to prevent the trial of massive human rights abuses. The new democratic Congress, however, declared the self-amnesty law void, and the government promoted historic human rights trials. Years later, the same democratic government, under the pressures of top military offices, passed two pardon-laws, which came to set limit to those trials (the punto final and obediencia debida laws). In a debatable decision (Camps), the Supreme Court considered that these laws were constitutionally valid. In 2007, in the Simón case, the Court had the opportunity to come back to the same issue. Simón was a police officer who, in association with other members of the police force, kidnapped José Liborio Poblete, his wife Marta Hlaczik, and their small daughter. The couple was tortured and then "disappeared," while the child was given to a military officer who registered her as his daughter. Simón had been prosecuted and convicted, in spite of the pardon-laws, because his crime -kidnapping a minor- was explicitly not covered by the pardon-laws. Still more significantly, in his decision, Judge Gabriel Cavallo accepted a complaint against Simón for the illegal detention, torture and disappearance of the Poblete-Hlaczik family. The Supreme Court then got the chance to revise this decision and, contradicting what it had said in Camps,

\footnotetext{
14 43. The Court considers that it should be emphasized that, in the light of the general obligations established in Articles 1(1) and 2 of the American Convention, the States Parties are obliged to take all measures to ensure that no one is deprived of judicial protection and the exercise of the right to a simple and effective recourse, in the terms of Articles 8 and 25 of the Convention. Consequently, States Parties to the Convention which adopt laws that have the opposite effect, such as self-amnesty laws, violate Articles 8 and 25, in relation to Articles 1(1) and 2 of the Convention. Self-amnesty laws lead to the defenselessness of victims and perpetuate impunity; therefore, they are manifestly incompatible with the aims and spirit of the Convention. This type of law precludes the identification of the individuals who are responsible for human rights violations, because it obstructs the investigation and access to justice and prevents the victims and their next of kin from knowing the truth and receiving the corresponding reparation.
} 
ratified that the two pardon-laws were void. ${ }^{15}$ Moreover, the Court maintained that the legislative decision annulling the pardon-laws were valid, and also stated the retroactive character of the invalidation of the pardon-laws, that is to say that human rights violators could not invoke those norms to prevent their own prosecution.

The reasons alleged by the majority in support of its ruling were extremely diverse, which makes it difficult to state precisely what was the final view of the Court on the topic (see Fernández Valle 2007). Most of the Justices made reference to some significant facts and legislative measures that had came out after the Court's decision in Camps, which merited obvious consideration -most significantly, the Congress' nullification of the impunity-laws in 2003. However, the crucial arguments for the majority of judges were undoubtedly those connected to the international law: the existing Human Rights treaties; the ius cogens and the duty to prosecute crimes against humanity and, most significantly, the Barrios Altos decision.

The most extreme position in the defense of this view was, paradoxically, that of Justice Petracchi. Petracchi was the only member of the majority who had participated in the Camps' decision that invalidated the pardon-laws. In this opportunity, and trying to justify his changing views, Petracchi mentioned the “imperative” need of following Barrios Altos. In addition, Judges Highton and Lorenzetti accompanied Petracchi in the use of similarly emphatic terms; while Judge Zaffaroni also maintained that the "clear decision of Barrios Altos demands us to (oppose the impunity laws)."16

In contrast, and in a dissenting opinion that is particularly interesting for our purposes, Justice Fayt clearly distinguished Barrios Altos from Simón. For Justice Fayt, precedents such as Barrios Altos were not applicable in the case under exam, because in Argentina the obediencia debida and punto final laws had been the product of a democratic process of debate, which had little to do with the vitiated deliberative process that had taken place in Peru, after Fujimori shut down Congress in 1992. To reach this conclusion, Justice Fayt made reference to numerous circumstances, including the fact that Argentina's pardon-laws were enacted by the new democratic government, rather than an illegal authoritarian government

\footnotetext{
${ }^{15}$ The Court had anticipated its new position in another significant decision, namely "Arancibia Clavel,” CSJN “Arancibia Clavel, Enrique Lautaro s/ homicidio calificado y asociación ilícita y otros -causa n. 259).

${ }^{16}$ In the Espósito, $M$ case, in 2003, Petracchi and Zaffaroni had already made reference to the obligatory character of international courts' decisions in the area. For them, "the scope of discretion of Argentina's tribunals" in the area had become "significantly reduced" after the novel jurisprudence of international courts. Moreover, many influential legal scholars in Argentina, had advanced arguments in the same direction, indicating that changes occurred at the level of the international law required Argentina's Court to revise its traditional view on the topic (discussing this issue, Filippini 2006; Abramovich 2007; Guembe 2005). See also Bakker (2005). Bakker, C. (2005), “A Full Stop to Amnesty in Argentina,” Journal of International Criminal Justice 3, 116-1120.
} 
for its own benefit; that the laws had been debated by Congress and public opinion, contrary to what had happened in Peru; and that their enactment had followed all the necessary legal steps, and included all the required controls (see Filippinni 2006).

At a personal level, I do not find Justice Fayt's arguments persuasive, particularly because I have serious doubts regarding the quality, depth and width of Argentina's collective debate regarding the pardon laws. However, I do think that he made an important point, which forces us to concentrate our attention on the democratic conditions under which the norm was produced -what I have named their inclusive character- rather than on the force that supports them. In Peru, the amnesty law was enacted after the closing of Parliament, and under conditions that limited freedom of the press and public debate. Impunity was then decided by an elite (an elite that included the beneficiaries of the amnesty law), with the exclusion of those who opposed it.

The cases of Barrios Altos and Simón invite us to reflect upon the same issue, namely the special respectability of those norms that emerge from an inclusive decision-making process. Nino challenged the validity of the self-amnesty law passed by the military government invoking precisely that argument; and Fayt referred to an essentiality similar point, which allowed him to point to crucial distinctions existing between the Simón and Barrios Altos cases. To ignore those differences of origin, to ignore the implications of creating a norm through an exclusionary process, is to miss something that is absolutely crucial for reflecting upon the impartiality, the validity and applicability of legal decisions.

In sum, all the examples so far examined, including the case of Argentina's selfamnesty law, allow us to recognize the potential of the deliberative approach for dealing with hard cases involving massive violations of human rights. The deliberative approach not only provides us with suggestions regarding how to organize the Criminal Process against human rights offenders, but also requires us to pay special attention to the contents of the Criminal Laws to be applied and the way they were created. In sum, it requires us to take the validity of those norms more seriously, paying particular attention to their inclusive and deliberative components -which proves to be extremely important in all cases, especially those involving the most extreme uses of the coercive powers of the State.

Deliberation and International Institutions

Having said this, I want to refer to two additional questions concerning the use of the deliberative approach facing situations of massive violations of human rights. The first one 
has to do with the role of international human rights courts; and the second has to do with the role of local tribunals before cases of gross human rights offenses.

The first question is whether the deliberative approach is or is supposed to be hostile to the intervention of international human rights tribunals. Such question may emerge given the importance that the deliberative view attributes to collective discussions within a particular community.

Now, it is true that, for the deliberative approach, there is no higher expression of the law but the one that emerges from an inclusive deliberation taking place in a self-governing community. However, and from that same starting point, it should also be clear that the deliberative approach does not need to oppose the intervention of foreign tribunals in cases of gross human rights' offenses. Rather, what the deliberative approach would do is reject two alternative and implausible responses regarding the role of international tribunals and, in general, international law.

The first response, which I call emphatic rejection, suggests, in principle, a radical rejection of the application of international law, particularly regarding human rights issues. Justice Scalia's opinion in Printz v. US may be a good illustration of this view (see also Valdés 2000, or Malamud Goti 1996, 2003). ${ }^{17}$ The second view, which I call emphatic acceptance, maintains the contrary position, and proposes a strong (and too commonly unreflective) approach to the local application of international law of human rights. This seemed to be the view adopted by Argentina’s Supreme Court in Simón (although I also think that this is a widespread view among international law experts).

The deliberative approach is clearly contrary to emphatic rejection; because -for principled reasons- it wants and needs to be open to international experiences and discussions. Mores specifically, the deliberative view maintains the importance of being open to foreign experiences, principles and viewpoints that may be illuminating for improving our own decisions, particularly when we are dealing with grave human rights' problems, which require serious reflection. This attitude of openness is particularly advisable, if not simply required, for those communities that are or have been controlled by authoritarian leaders who prevented or put obstacles to the introduction of critical ideas about their enacted laws and adopted policies. This becomes more important when we recognize -as Duff does- that "a

${ }^{17} 521$ U.S. 898, $921 \mathrm{n.11}$ (1997). He claimed that "We think such comparative analysis inappropriate to the task of interpreting a constitution ..."; 
regime is unlikely to put its own officials on trial; even when it falls, its successor might be reluctant to prosecute such crimes.”

The deliberative approach is also against emphatic acceptance, because it proposes a critical (rather than dogmatic) approach to international law. The deliberative view does not assume -as many authors do- that decisions of international institutions are an expression of "superior" and unquestionable law. In fact, this approach maintains that many international institutions and decisions lack the strong authority and legitimacy that they claim to have (most of us -even reasonably informed people- know almost nothing about international organizations -i.e., the Inter American Human Rights Court-; their composition; the way to accede to these tribunals; the way to challenge their decisions; etc.). By stating this I challenge, for example, the idea that "any...international tribunal satisfying the conditions of natural justice may exercise (universal jurisdictions” (Luban 2004, 143). (Luban, for example, associates the impartiality of the tribunal with the "professionalization" and "isolation" of its members). In sum, the deliberative view pays attention both to the legitimacy-problem that affects numerous international organizations, and stresses the importance of being open to discussions developed everywhere in the world, particularly in the case of societies emerging from authoritarian rule.

\section{Deliberation and Local Tribunals}

The last question that I want to explore here concerns the role of local tribunals in communities that have suffered from gross human rights' violations. This question needs to be examined from very different angles, but here I just want to deal with one aspect of it. In my opinion, Latin American tribunals have been moving rather spasmodically as regards human rights causes. Frequently, they assumed an attitude of systematic judicial passivism, while in other occasions they assumed just the opposite position, one that I will call judicial imposition.

Chilean tribunals, for example, have normally assumed a position of extreme deference and self-restraint, in most publicly disputed cases, including the crucial cases related to gross human rights violations that emerged during and after the government of General Pinochet. This extreme passivism moved former President Aylwin, for example, to publicly criticize members of the Supreme Court for their lack of "moral courage." In a speech made on public television, after the Court tried to counter attacks against its passivism (the Court had said that those attacks were "passionate, reckless, and biased”) Aylwin stated 
that Chilean courts "had shown a lack of moral courage in the face of the vast human rights violations perpetrated by the military regime” (Couso 2006, 75). Couso, J. (2006), “The Politics of Judicial Review in Chile,” in S.Gloppen, et al, Democratization and the Judiciary, Frank Cass, London.

Argentinean tribunals, instead, have recently adopted the contrary attitude, namely one of extreme activism. In this respect, the Simón decision only represented one of the latest and more important examples of their new activist attitude. Through its decision, the Supreme Court re-opened the possibility of prosecuting former military officers, which seemed impossible until then, as a consequence of the pardon-laws that the Court's previous decision in Camps had considered valid.

The Court's response in Simón was the last step of an erratic and always dramatic human rights' policy that involved the three democratic branches over a period of almost 30 years. Briefly summarizing this long story, one should make reference to the serious human rights violations by the Proceso Militar that began in 1976; the self-amnesty law passed by the same military regime in 1983, trying to prevent prosecution for the atrocities committed by most of its members; the democratic invalidation of the self-amnesty law; a principled policy of trials against human rights offenders inaugurated by democratic President Alfonsín at the end of 1983; the laws of punto final and obediencia debida passed by same President Alfonsin in 1987, with the aim of limiting the impact of the trials that he himself had promoted; the indultos enacted by President Menem, trying to inaugurate a policy of "forgetting;" the nullification of the pardon-laws (symbolically) decided by the same legislative that had created them; and contradictory Supreme Court decisions, which included incongruous sentences such as Camps and Simón (the first validating the pardon-laws, and the second invalidating them). This story -it seems clear to me- cannot be considered the expression of a collective, ongoing, progressive, open-ended reflection, but rather a succession of good-will or bad-faith impositions from one or other sectors of society or official institutions, on the rest of society.

More specifically, and always from the perspective of deliberative democracy -I maintain- both the attitudes of systematic passivism and judicial imposition must be condemned. A court that is inspired by a deliberative conception could and should play a completely different role, when facing extreme violations of rights. The court should see itself as participating in a collective construction of social agreements, in the process of finding of communal solutions to problems that so profoundly affect the entire community. According to the deliberative view, courts could and should help the political branches -and, 
in the end, the people at large- to improve their decisions, which according to this view implies making public decisions more inclusive, better informed, more debated. They fail to fulfil their role, instead, when they remain silent -as if they were not co-responsible of each and every violation of constitutional rights that occurred in a certain community- or when they simply try to impose their own views on how to solve those violations on political authorities.

Courts, it must be noted, are institutionally placed in an exceptional position for contributing to foster deliberation: the Judiciary is the institution in charge of receiving complains from all those who are or feel they have been unduly treated by the decisionmaking process. There is no other institution whose corridors are daily filled by those in need of help and public attention. Judges are (quite) naturally inclined to look at the political system from the perspective of those who suffer from it - they are required to look at this system paying attention to its weaknesses, failures and ruptures. Even better than that, judges are institutionally obliged to listen to the different parties in a conflict - and not only to the side that claims to have been mistreated.

Now, it is not only that judges are institutionally well-placed to enrich the deliberative process and help it correct some of its improper biases. It is also the case that judges have many different tools that facilitate their task in this respect, as it has been ratified by the actual practice of judicial review. For one thing, and as a consequence of their institutional position and the means they have at their disposal, judges have very good chances of detecting how the deliberative process is working. At the same time, judges have many chances of acting in ways that are respectful to the people's final authority: they have sufficient techniques and procedural means that allow them to act consequently. They may decide to remand a certain norm to Congress, forcing it to think twice about that norm; they may declare that a certain right has been violated, without imposing a particular solution to the legislators; they may establish that a certain violation of rights needs to be remedied within a certain timeframe, without taking the place of the legislator for deciding what remedy to adopt; they may offer the legislator a set of alternative remedies, leaving up to them the final decision of which one to choose.

Massive violations of human rights represent the most traumatic events that a society can experience. The cure to those profound injuries requires justice, and justice requires -I 
believe- from an inclusive collective discussion in which courts do need to take part, helping the rest of us critically reflect on what we did or did not do to prevent them from happening.

\section{BIBLIOGRAFIA}

Abramovich, V. (2007), “Editorial,” Nueva Doctrina Penal, 2007-B, I-XVIII.

Arendt, H. (2006), Eichmann in Jerusalem: A Report on the Banality of Evil, Penguin Classics, London.

Braithwaite, J. \& Pettit, P. (1990), Not Jut Deserts: A Republican Theory of Criminal Law, Oxford: Clarendon Press.

de Greiff, P. (2002) Deliberative Democracy and Punishment Buffalo Criminal Law Review, vol. 5, n. 2, 373-403.

Duff, A. (1986), Trials and Punishments, Cambridge: Cambridge University Press.

Duff, A. (2001), Punishment, Communication, and Community, Oxford: Oxford University Press.

Duff, A. (2008), “Authority and Responsibility en International Criminal Law,” to appear in S. Besson and J. Tasioulas, eds., Philosophy of International Law, Oxford: Oxford University Press.

Duff, A. \& Garland, D. (1994) A Reader on Punishment, Oxford: Oxford University Press.

Epstein, L. \& Knight, J. (2003), “Constitutional Borrowing and Nonborrowing,” 1 International Journal of Constitutional Law 196.

Feinberg, J. (1965), “The Expressive Function of Punishment,” The Monist, 49, 397-423.

Fernández Valle, M. (2007), "La Corte Suprema, la dictadura militar, y un fallo para pensar,” Revista Argentina de Teoría Jurídica de la Universidad Torcuato Di Tella.

Filippini, L. (2006), "Tres problemas en la aplicación del derecho internacional en el caso Simón", en Revista de Derecho Penal, (Marzo), Lexis Nexis, Buenos Aires.

Guembe, M. (2005), “La reapertura de los juicios por los crímenes de la dictadura militar argentina," Sur, 3-2.

Habermas, J. (1996), Between Facts and Norms; Cambridge: MIT Press.

Hampton, J. (1984), “The Moral Education Theory of Punishment,” Philosophy and Public Affairs, vol. 13, n. 3, 208-238.

Kahn, P. (1999), “On Pinochet,” Boston Review, Feb.Mar. http://bostonreview.net/BR24.1/kahn.html. 
Loveman, B. \& Lira, E. (2002), El espejismo de la reconciliación política. Chile 1990-2002, LOM Ediciones, Santiago de Chile.

Luban, D, (2004), “A Theory of Crimes Against Humanity,” Yale Journal of International Law, 29, 85.

Macedo, S. (2003), ed., Universal Jurisdiction, Penn.: University of Pennsylvania Press.

Malamud Goti, J. (1996), Game Without End: State Terror and the Politics of Justice, Oklahoma.

Malamud Goti, J. (2003), ed., Los dilemas morales de la justicia internacional. El caso Pinochet, Miño y Dávila, Buenos Aires.

Maurino, G. (2008), “A la búsqueda de un pasado,” en R. Gargarella ed., Teoría y Crítica del Derecho Constitucional, Lexis Nexis, Buenos Aires.

Nino, C. (1983), "A Consensual Theory of Punishment", Philosophy and Public Affairs, vol. 12, 289-306

Nino, C. (1986), “Does Consent Override Proportionality,” Philosophy and Public Affairs, vol. 15, no. 2. (Spring), 183-187.

Nino, C. (1996), Radical Evil on Trial, Conn.: Yale Univ. Press.

Nino, C. (1996b), The Constitution of Deliberative Democracy, Conn.: Yale Univ. Press.

Pettit, P. (1997), Republicanism, Oxford: Oxford University Press.

Tushnet, M. (1999), “The Possibilities of Comparative Constitutional Law,” 108 Yale Law Journal 1225.

Valdés, F. (2000), "Postcolonial Encounters in the Development of International Human Rights,” 9 U. Miami Int'l and Comp. L. Rev. 189.

Veloso, P. (2003), “Al fin de cuentas, el objetivo es la justicia,” en J.Malamud Goti, ed., Los dilemas morales de la justicia internacional, Ed. Miño y Dávila, Buenos Aires.

Waldron, J. (1999), Law and Disagreement, Oxford: Oxford University Press. 